\title{
Ancient Machu Picchu Drainage Engineering
}

\author{
Kenneth R. Wright \\ Alfredo Valencia \\ William L. Lorah
}

\begin{abstract}
The drainage infrastructure constructed by the Inca at ancient Machu Picchu represents a significant public works achievement. The difficult site constraints associated with the nearly $2,000 \mathrm{~mm}$ per year of rainfall, steep slopes, landslides, and inaccessibility posed drainage challenges that were met successfully by the Inca. The technical analysis of the Inca drainage works demonstrates that the drainage criteria used were reasonable and the implementation exceptional, and that the Inca were good engineers even though they labored without the benefit of a written language or the use of a wheel. Proof of the Inca success with drainage rests with the fact that Machu Picchu lay in the rainforest for 400 years without failure. There is no better example of successful ancient civil engineering than Machu Picchu. It was built by Native Americans before the arrival of the Spanish Conquistadors, was essentially abandoned in 1540 A.D., and endured for $41 / 2$ centuries under a thick rainforest until the 20th century. Scientists, engineers, and laymen alike continue to marvel at the wonders of Machu Picchu.
\end{abstract}

\section{INTRODUCTION}

When Professor Hiram Bingham returned to Yale University after his discovery of Machu Picchu, Peru, in 1911, he stated that "the Inca were good engineers" (Bingham 1913). Recent engineering research at Machu Picchu has demonstrated that Bingham was correct. This paper describes the carefully planned and constructed drainage infrastructure at Machu Picchu, without which it would not have endured to the present (Fig. 1).

Machu Picchu served a permanent population of about 300 with a peak of 1,000 when the Inca emperor was in residence. When Bingham stumbled upon the ruins of the beautiful Andean Inca community, it had endured nearly intact for over four centuries without suffering from foundation failures or landslide damage (Bingham 1930) (Fig. 2). The potential ravages of time, steep mountain slopes, and excessive rainfall were overcome by the exceptional ability of the Inca engineers to construct good building foundations and install effective drainage systems. These two Inca achievements delivered Machu Picchu to the 20th century scientists in a condition nearly as it had existed when it was abandoned in the 16th century. It was occupied between 1450 and 1540 A.D., with some people remaining until 1572 A.D. (Rowe 1990).

Machu Picchu, the royal estate of the Inca ruler Pachacuti (Rowe 1990), is the most well known of all Inca archeological sites. While numerous visitors view the site in awe each year, little was known about its paleohydrology or surface and subsurface drainage, or how the various infrastructure components of this Andean community functioned. It was for this reason that the Peruvian government issued an archeological permit to the writers in 1994 to carry out research on the agriculture, water supply, hydraulics, and drainage of this ancient Andean community (Wright 1996); this paper deals with its surface and subsurface drainage.

When viewing the complex but orderly layout of the ruins, scientists and laymen alike express wonder and ask questions about the drainage and potential irrigation of the numerous agricultural terraces. Because the annual average precipitation likely was about $1,940 \mathrm{~mm}$ per year at the time of occupation, there was no need to irrigate agricultural land at Machu Picchu, and field investigations by the writers indicated that no irrigation delivery or distribution system existed [Wright et al. 1997(c)]. Fig. 3 presents the ice core data from the Quelccaya ice cap, representing long-term precipitation patterns (Thompson et al. 1992; Thompson and Moseley-Thompson 1989). The Machu Picchu period is shown for comparison. 


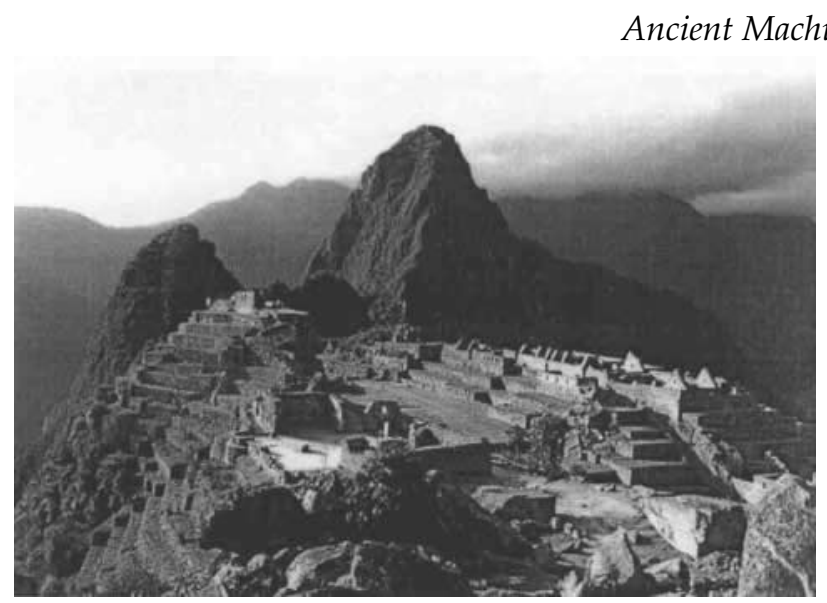

Figure 1. Machu Picchu Was in Good Condition after Four Centuries of Rain Forest Growth When Discovered by Yale Explorer Hiram Bingham in 1911. Its Longevity and Resistance to Landslides and Settlement Are Result of Extensive Drainage Systems Built by Inca in 15th and 16th Centuries.

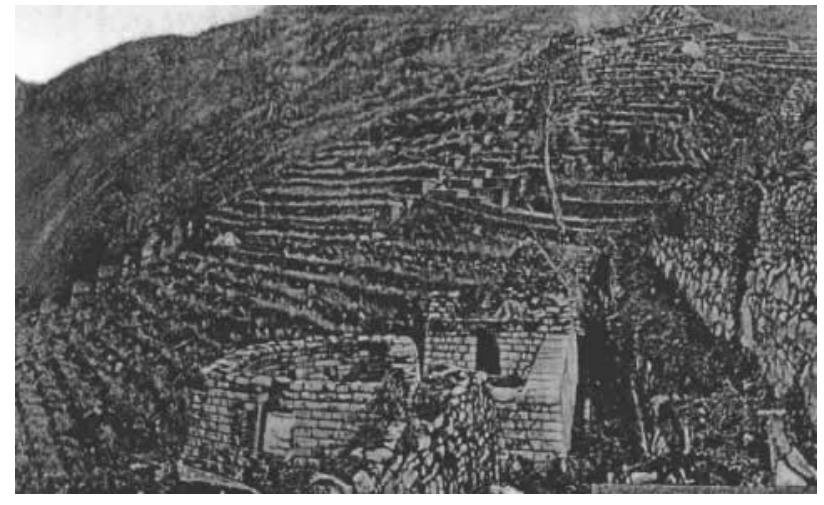

Figure 2. Hiram Bingham's 1912 Photo of Machu Picchu Agricultural Terraces Showing Hundreds of Undamaged Stone Walls That Resisted Landslides and Earthquakes. Surface and Subsurface Drainage Works Were Built to Handle 1,940 mm of Average Annual Rainfall. Temple of the Sun Is Shown in Foreground with Its "Most Beautiful Wall" Intact on Right (Bingham 1930).

\section{SETTING AND GEOLOGY}

The Inca royal estate of Machu Picchu is situated on a high mountain ridge between two prominent peaks at an elevation of 2,438 m (Fig. 4). The ridge plunges precipitously on both sides some $450 \mathrm{~m}$ to the Urubamba River. It would appear to be an unlikely location for ancient peoples to have been able to construct a complex of beautiful buildings that would endure for so long a time.

Machu Picchu is about 1,400 km south of the equator on the eastern slope of the Peruvian Andes (Fig. 5). The site lies near the headwaters of the Amazon River, at long. $72^{\circ} 32^{\prime} \mathrm{W}$ and lat. $13^{\circ} 9^{\prime} \mathrm{S}$. Machu Picchu is laid out like a patchwork quilt on a mountain ridge between two prominent mountain peaks-Machu Picchu and Huayna Picchu. The dramatic site is a manifestation of tectonic forces and valley down, cutting by the Urubamba River, which meanders along three sides of the ridgetop retreat. Further away, but visually dominating, is the icecapped peak of Mount Veronica to the east $(5,850 \mathrm{~m})$.

This Inca site lies within the Cordillera Oriental (Eastern Cordillera) between the High Plateau and Subandine zones of the Peruvian Andes (Marocco 1977) on a $40 \mathrm{~km}^{2}$ portion of the complex Vilcabamba Batholith (Caillaux n.d.). This 250-million-year-old intrusion is white to gray-colored granite, characterized by its abundance of quartz, feldspar, and mica (predominantly biotite). This mineralogical composition made the granite of Machu Picchu a durable construction material. Nonetheless, it was the inherent, rectangular joint pattern that the Inca workmen recognized and masterfully used as building stones to construct Machu Picchu [Wright 1997(b)].

The most significant geologic characteristics of the Machu Picchu site are the numerous faults and abundant rock fractures. Two principal faults are named for the two prominent local peaks: Huayna Picchu Fault and Machu Picchu Fault, as shown in Fig. 4. These high-angle reverse faults formed a wedge-shaped structural block relative to their namesakes. This block, or graben, is the structure on which the ancient Inca people built their city. The 
Machu Picchu Fault influences the location at which the Machu Picchu spring emerges. Increased permeability along upgradient portions of the fault system allows for infiltration of precipitation and its emergence at the spring site, thus providing a perennial water source to the Inca people [Wright 1997(b)].

The Machu Picchu fault system is also responsible for much of the topographic relief in the vicinity of the mountain sanctuary. The orientation of the fault system can be identified by aligning the near-vertical northwestern face of Machu Picchu with the linear reaches of the nearby Urubamba River along the southeastern flank of Putucusi (Fig. 4).

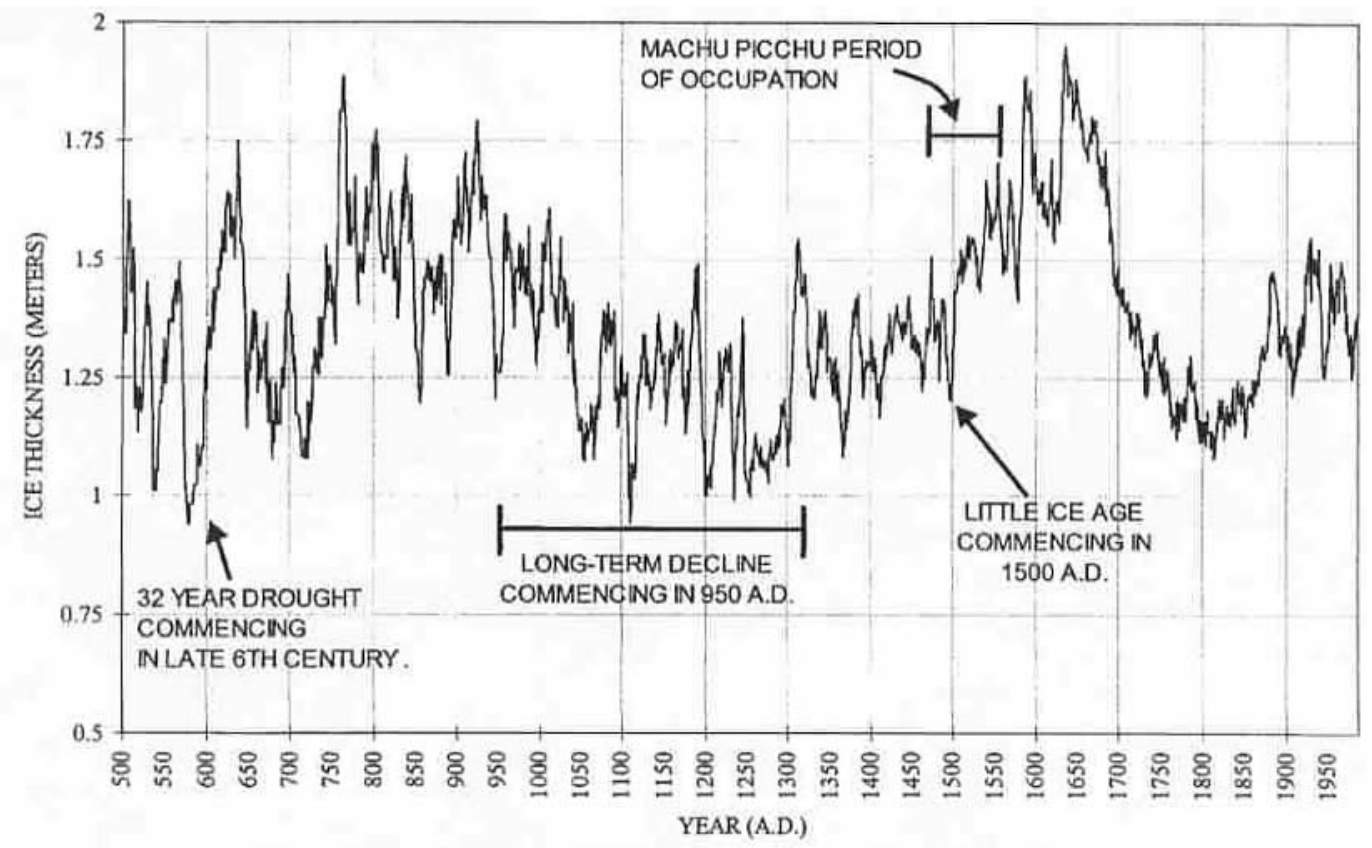

Figure 3. Long-Term 10-Year Running Average of Precipitation Based on Quelccaya Ice Cap Cores by Byrd Polar Research Center at Ohio State University. Machu Picchu Primary Occupation Period Is Shown from 1450 to 1540 AD.

\section{SOILS OF MACHU PICCHU}

The characteristics of the soil in the agricultural terraces were determined from 16 of the writers' soil samples tested by Dr. James Self of Colorado State University (CSU) Soil, Water, and Plant Testing Laboratory in 1996 (Wright Water Engineers 1996).

The writers had requested permission from Peruvian government representatives in February 1995 to take six core samples from the terraces; however, the request was denied. Instead, the Instituto Nacional de Cultura (INC) archaeologist, Snta. Elva Pino, commenced the formal excavations of six terrace sites and the collection of over 100 soil samples from three strata at each test pit [Wright 1997(a)].

Soil samples were delivered to the writers by the INC Cusco director, along with a government resolution authorizing their transfer to the United States. The CSU laboratory conducted a full array of agronomic tests on the ancient soils. A summary of the results is presented in Table 1. The soils were found to be deficient in numerous nutrient and macronutrient constituents, probably as a result of four and a half centuries of in situ leaching and drainage of the substantial rainfall [Wright1997(a)].

The excavations and laboratory test results show that the topsoil was typically $0.5 \mathrm{~m}$ thick, and that even at greater than $1 \mathrm{~m}$ deep, the subsoil of the deeper strata contained topsoil characteristics. Fortunately, the discovery of a gold bracelet in Test Pit No. 6 justified additional archaeological excavations by the INC scientists during 1996. The subsequent and more extensive excavations have shown a deep subdrainage system, representing the work of a well-organized and committed corporate agricultural society having knowledge of the importance of good drainage of soil for sustained agricultural production and foundation stability ( Fig. 6). Fig. 7 shows the stability of the agricultural terraces that supported the domestic water supply canal.

The topsoil in the 4.9 hectares (ha) of the agricultural terraces was hand placed. The source of the soil, whether from the Urubamba River floodplain far below Machu Picchu or from the slopes of nearby mountains, could not be specifically identified from topsoil and sand particle characteristics and configurations. 
The Machu Picchu agricultural soils were determined to have good moisture-holding characteristics suitable for sustaining crops in drier months, good agricultural soil texture, more than adequate soil horizon thickness, and good drainage. The underlying subsurface drainage system was found to be excellent.

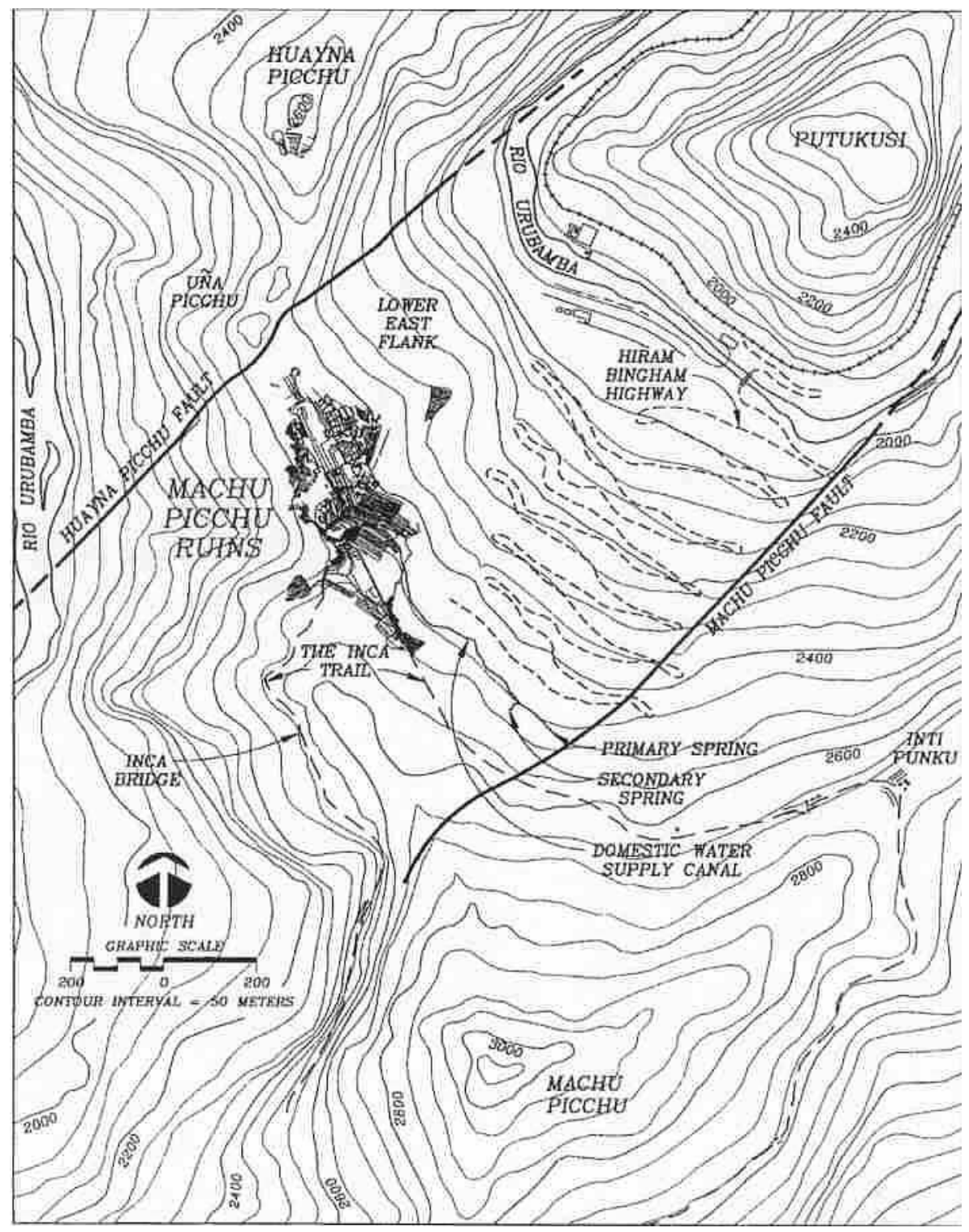

Figure 4. Machu Picchu and Environs, Showing Two Main Geologic Faults Associated with Machu Picchu, and Two Bordering Mountains of Huayna Picchu and Machu Picchu. Across River Is Mountain of Putucusi.

\section{CLIMATE}

Machu Picchu lies $13^{\circ}$ south of the equator and has a dry winter season (May through August) and a rainy summer season (October through March). The temperature of Machu Picchu is mild, and there is no frost period. Seasonal temperature variations are considered modest. The precipitation and temperature characteristics are summarized in Table 2.

The ancient climate character was estimated using the published results of a 1,500-year ice core analysis and correlating it with modern data collected at Machu Picchu. The ice core samples were from the Quelccaya ice cap, located approximately $250 \mathrm{~km}$ southeast of Machu Picchu (Fig. 5). These data reflect the general historic regional climate affecting ancient Machu Picchu and were used in estimating the ancient climate. The detailed and extensive ice cap and glacier studies by the Byrd Polar Research Center at Ohio State University were conducted by Thompson et al. (1985), who recovered two cores from the glacier. One core represents the years 470 to 1984 , and the other represents the years 744 to 1984 . These ice-coring data define wet and dry cycles extending from 
470 to 1984 as shown in Fig. 3 (Thompson et al. 1984). The long- term (470 through 1984) average annual ice layer thickness for the two ice cores is about $1.4 \mathrm{~m}$, estimated to represent $1,990 \mathrm{~mm}$ of annual precipitation.

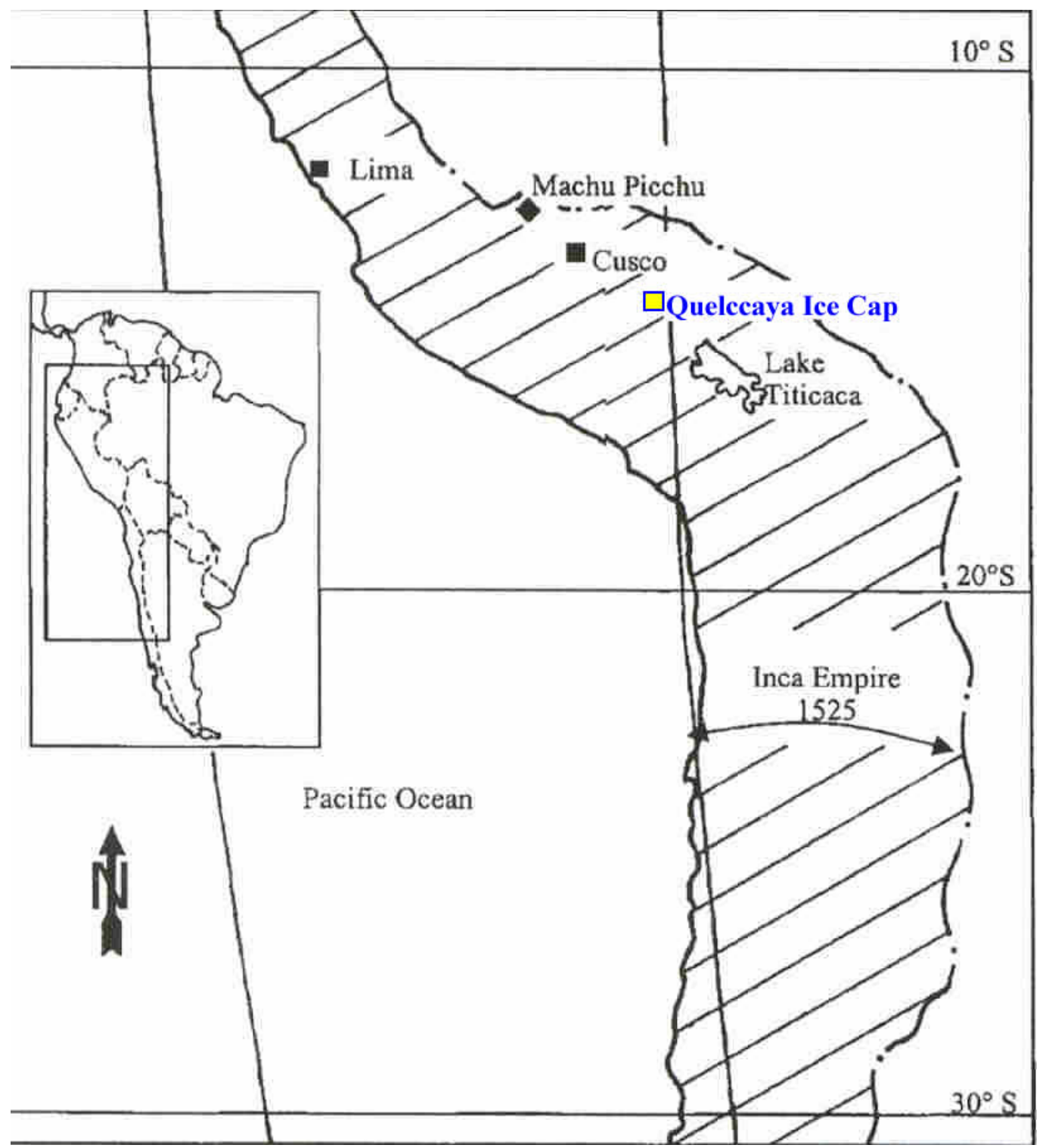

Figure 5. Map of Inca Empire at Time of Arrival of Conquistador Pizarro in 1532. Machu Picchu Is Located 80 km Northwest of Inca Empire Capital of Cusco. Lima Is Shown Only for Orientation.

For the modern period, available on-site climatological data from 1964 through 1977 were selected for analysis of agricultural potential at Machu Picchu. The 1964 through 1977 ice cap record shows an average ice layer thickness of $1.38 \mathrm{~m}$, or about $99 \%$ of the long-term normal ice thickness ("Tropical" 1986). For the 90-year period of primary occupation of Machu Picchu, the estimated decadal precipitation, as represented by ice layer accumulations, is presented in Table 3, with the 1964 through 1977 period of ice accumulation shown at the bottom for comparison. The 1964 through 1977 precipitation, then, was similar to that of the Machu Picchu period of occupation. The monthly precipitation recorded at Machu Picchu from May 1964 through December 1977 is presented in Table 4, based on data from SENAMMi (Servicio Nacional de Meteorologia e Hidrologia), Cusco, Peru.

It can be noted that the first 50 years of occupation at Machu Picchu were drier than the last 40 years. A marked increase in ice layer thickness began in about 1500. This coincided with the well-documented Little Ice Age in the northern hemisphere (Thompson et al. 1986). The precipitation for the 1450 through 1500 period, based on annual ice pack accumulation, was approximately $1,830 \mathrm{~mm}$, or about $8 \%$ below the 470 to 1984 long-term average of $1,990 \mathrm{~mm}$. The 1500 through 1540 period, on the other hand, was $5 \%$ wetter than the long-term average with an equivalent annual precipitation of about $2,090 \mathrm{~mm}$. As a result of the evaluation of the Quelccaya ice cap data 
and the finding that the modern period precipitation was $99 \%$ of the long-term average and only $1 \%$ greater than the 1450 to 1540 precipitation, the writers concluded that the modern period average annual precipitation data were reasonably representative of the period-of-occupation average precipitation. The annual variations may have been just as severe as those indicated by the modern data (Table 4).

Table 1. Table 1. Topsoil Gradation in Strata I Machu Picchu Agricultural Terraces

\begin{tabular}{|c|c|c|c|}
\hline \multicolumn{4}{|c|}{ Particle Size Gradiation } \\
\hline Particle Size & \% Retained & Particle Size & \% Retained \\
\hline$<2 \mathrm{~mm}$ & 15 & $250 \mathrm{um}$ & 14 \\
\hline $1 \mathrm{~mm}$ & 10 & $106 \mathrm{um}$ & 15 \\
\hline $500 \mathrm{um}$ & 16 & $53 \mathrm{um}$ & $\%$ \\
\hline \multicolumn{5}{|c|}{} \\
\hline Constituent & $\%$ & Constituent & 17 \\
\hline Sand & 66 & Clay & Sandy Loam \\
\hline Silt & 17 & Texture & \\
\hline
\end{tabular}

\section{AGRICULTURAL TERRACES}

The agricultural terraces of the Inca royal retreat of Machu Picchu complement the magnificent structures of this mountaintop sanctuary, both physically and aesthetically. The terraces also provided protection from uncontrolled runoff and hillside erosion.

The numerous ancient agricultural terraces, including those found on the lower flanks below Machu Picchu, total 4.9 ha as determined by field and office studies by the writers. They are formed by stone retaining walls, contain thick topsoil, and are well drained (Valencia and Gibaja 1992). Deeper Strata II and III were more granular than the Strata I topsoil, which provided higher permeability to enhance subsurface drainage. In deeper strata the Inca workmen provided excellent subsurface drainage with larger stones and sometimes with stone chips from the stonecutting efforts.

Field investigations were conducted to define the agricultural drainage, any potential irrigation water sources, canals to conduct irrigation water to the agricultural sector, and any means to carry water to each of the many terraces. The only outside water sources found at Machu Picchu were the domestic water supply springs on the north face of Machu Picchu Mountain, the water of which was conveyed to the urban sector fountains via a small domestic water supply canal (Fig. 7). The canal traverses the agricultural sector, but there are no turnouts to the terraces. Field investigations were also made to determine whether or not drainage water was reused for irrigation purposes. No evidence of reuse of drainage water for irrigation was found within the Machu Picchu ruin. Neither was the discharge from the domestic water supply fountains reused for irrigation, but merely discharged to the main drainageway. However, evidence was found that shows that agricultural drainage water, along with basin subsurface runoff, was captured for several stone-formed fountains among the lower terraces downhill from Machu Picchu [Wright et al. 1997(a)].

Evaluation of the estimated ancient rainfall showed that there was adequate water for crops without having to resort to irrigation. This, along with the on-site studies, demonstrated that there was no irrigation at Machu Picchu. 


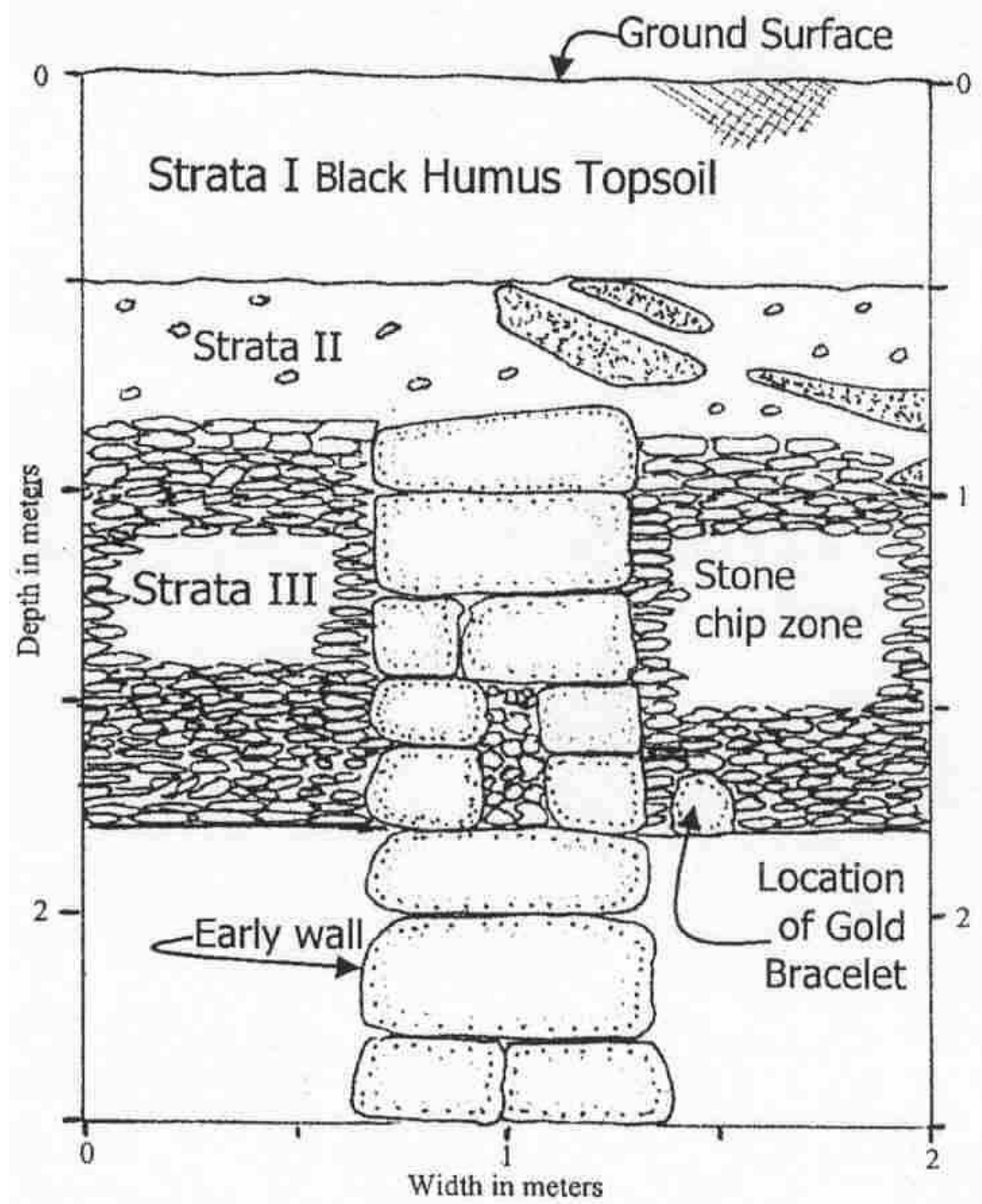

Figure 6. Test Pit in Plaza Area Showing Soil Profile, Sand Lenses, Early Wall, Stone Chip Drainage Zone, and Location of First and Only Gold found at Machu Picchu. 


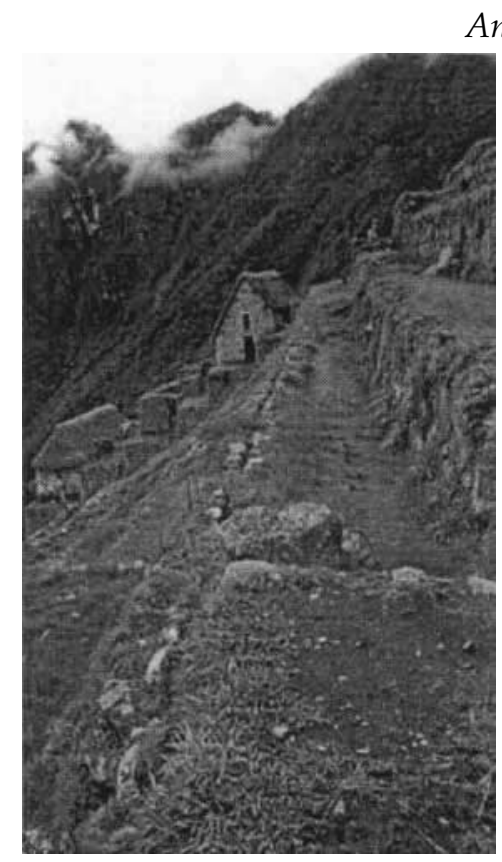

Figure 7. Canal with Qolqas (Storehouses) and Terraces in Agricultural Sector. Water Supply Canal and Agricultural Terraces Were Found in Good Condition by Bingham in 1911, Attesting to Excellent Engineering of Ancient Incas.

\section{URBAN SECTOR}

The urban sector of Machu Picchu covers 8.5 ha and contains approximately 172 buildings, most of which were covered with thatched roofs. These residential and temple areas of Machu Picchu were laced with granite stairways and walkways, many of which also provided routes for drainage channels. Situated throughout the urban development in the retaining walls and building walls are numerous surface drainage channels that, when coupled with the drainage channels and subterranean chambers, define the drainage network. The density of buildings with impermeable thatched roofs resulted in a generally high coefficient of runoff with a short time of concentration for the rainfall-runoff relationships.

Table 2. TABLE 2. Summary of Precipitation in Millimeters and Inches (1964-1977)

\begin{tabular}{|c|c|c|}
\hline Precipitation (1) & Millimeters (2) & Inches (3) \\
\hline Average annual & 1,960 & 77.2 \\
\hline Maximum annual & 2,400 & 94.4 \\
\hline Minimum annual & 1,490 & 58.6 \\
\hline Average May-August & 196 & 7.70 \\
\hline Average October-March & 1,472 & 58.1 \\
\hline
\end{tabular}

Table 3. TABLE 3. Annual Precipitation at Machu Picchu during Occupation by Decade

\begin{tabular}{|c|c|}
\hline Decade (1) & Precipitation (mm per year) \\
\hline $1450-1459$ & 1,770 \\
\hline $1460-1469$ & 1,900 \\
\hline $1470-1479$ & 1,830 \\
\hline $1480-1489$ & 1,770 \\
\hline $1490-1499$ & 1,860 \\
\hline $1500-1509$ & 2,020 \\
\hline
\end{tabular}


Ancient Machu Picchu Drainage Engineering

\begin{tabular}{|c|c|}
\hline Decade (1) & Precipitation (mm per year) \\
\hline $1510-1519$ & 2,150 \\
\hline $1520-1529$ & 1,980 \\
\hline $1530-1539$ & 2,220 \\
\hline Average & 1,940 \\
\hline $1967-1977$ & 1,960 \\
\hline
\end{tabular}

Table 4. Table 4. Monthly Precipitation at Machu Picchu in Millimeters. [Source: SENAMMi (Servicio Nacional de Meteorologia e Hidrologia), Cusco, Peru].

\begin{tabular}{|c|c|c|c|c|c|c|c|c|c|c|c|c|c|}
\hline $\begin{array}{l}\text { Month } \\
\text { (1) }\end{array}$ & $\begin{array}{l}\text { Jan- } \\
\text { uary } \\
\text { (2) }\end{array}$ & $\begin{array}{l}\text { Febru- } \\
\text { ary (3) }\end{array}$ & $\begin{array}{l}\text { March } \\
\text { (4) }\end{array}$ & (5) & (6) ${ }^{\text {May }}$ & June & (8) July & $\begin{array}{l}\text { Au- } \\
\text { gust } \\
\text { (9) }\end{array}$ & $\begin{array}{l}\text { Septen } \\
\text { ber } \\
(10)\end{array}$ & $\begin{array}{l}\text { Octo- } \\
\text { nber } \\
\text { (11) }\end{array}$ & $\begin{array}{l}\text { Novem } \\
\text { ber } \\
(12) \\
\end{array}$ & $\begin{array}{l}\text { De- } \\
\text {-cem- } \\
\text { ber } \\
\text { (13) }\end{array}$ & $\begin{array}{l}\text { An- } \\
\text { nual } \\
\text { (14) }\end{array}$ \\
\hline $\begin{array}{l}\text { Aver- } \\
\text { age }\end{array}$ & 285 & 321 & 304 & 183 & 49 & 33 & 47 & 66 & 102 & 153 & 171 & 241 & 1,955 \\
\hline $\begin{array}{l}\text { Num- } \\
\text { ber of } \\
\text { Years }\end{array}$ & 11 & 12 & 12 & 11 & 12 & 12 & 13 & 12 & 12 & 13 & 13 & 13 & --- \\
\hline $\begin{array}{l}\text { Mini- } \\
\text { mum }\end{array}$ & 231 & 227 & 148 & 58 & 0 & 2 & 15 & 27 & 24 & 58 & 79 & 142 & 1,489 \\
\hline $\begin{array}{l}\text { Maxi- } \\
\text { mum }\end{array}$ & 381 & 449 & 339 & 311 & 124 & 111 & 132 & 126 & 191 & 293 & 313 & 303 & 2,398 \\
\hline
\end{tabular}

\section{DRAINAGE}

The drainage at Machu Picchu and its special characteristics represent the secret of its longevity. This has long been overlooked by archaeologists and scientists. Without good drainage and foundation construction, there would not be much left of the royal estate of Emperor Pachacuti. The buildings would have crumbled and many of the agricultural terraces would have collapsed due to the high rainfall, steep slopes, slideprone soils, and settlement.

Surface and subsurface drainage at Machu Picchu was given high priority during its design and construction. For instance,one can say that the miracle of Machu Picchu is not the beautiful buildings, which have been the subject of past archeological studies, but the engineering features, which lie unseen underneath the ground, where some $60 \%$ of the Inca construction effort centered.

The drainage system at Machu Picchu has eight major components, summarized as follows:

1. A centralized Main Drain serving to separate the Agricultural Sector from the Urban Sector (Fig. 8).

2. Agricultural terrace surface drainage with good longitudinal slopes to formal surface channels integrated with access stairways or to the main open drain.

3. Subsurface drainage of agricultural terraces at depth, typically consisting of ungraded rock chips and stones overlaid with a layer of gravel and, above that, a layer of somewhat sandy material.

4. Positive surface drainage of urban grassed or soil areas to drain the runoff from the many thatched roof structures and plaza areas. In some places, thatched roof drip channels were cut into rocks (Fig. 9).

5. Urban and agricultural drainage channels combined with stairways, walkways, or even temple interiors.

6. Deep subsurface strata under plazas of rock chips and stones (Fig. 6) to allow the plazas to receive and infiltrate runoff from tributary areas. 
7. A well-conceived and strategically placed urban area system of 129 drain outlets placed in the numerous stone retaining and building walls (Fig. 10).

8. Subterranean caves strategically used for drainage discharge, with relatively free subsurface flow via natural underlying permeable deposits of granite rock falls.

\section{ANNUAL WATER BUDGET}

An annual water budget was used to estimate the amount of water yield, both surface and subsurface, using the following parameters [Wright 1997(c)].

- Annual average rainfall 1,940 mm

- Agricultural vegetation evapotranspiration 1,200 mm

- Composite unit urban area evaporation and evapotranspiration $600 \mathrm{~mm}$

It was estimated that the agricultural terraces yielded $7,400 \mathrm{~m}^{3} / \mathrm{ha} /$ year. The urban area is estimated to have yielded $13,400 \mathrm{~m}^{3} / \mathrm{ha} /$ year.

Based upon examination of the topography, lack of erosion, type of soils, likely vegetation cover, and subsurface drainage potential, it is estimated that about $90 \%$ of the annual precipitation infiltrated and $10 \%$ resulted in surface runoff. On the other hand, in the urban area, approximately $60 \%$ would be surface flow, with $40 \%$ infiltrated because of the impermeability of the thatched roofs and compacted soils; however, much of the surface flow is later routed to the plaza areas for infiltration and to caverns.

The field survey of the Machu Picchu drainage system and the condition of the agricultural terraces and urban area buildings and walls proves that the capacity and character of the subsurface drainage system was generally adequate in terms of flow capacity and temporary detention storage to accept and transport the groundwater component of intense storms to the hillside below.

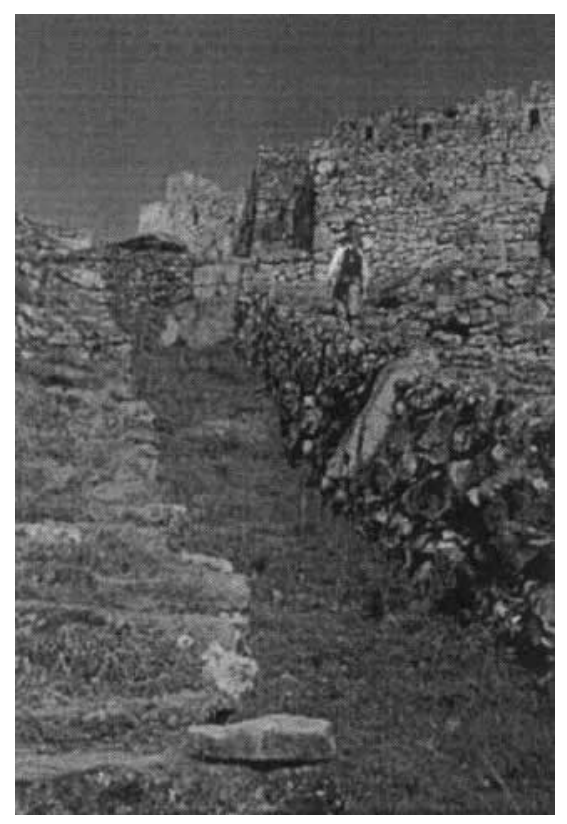

Figure 8. Main Drain of Machu Picchu, Sometimes called the Dry Moat, this Drain Overlaid Local Geologic Fault. Main Drain Discharges into Rainforest Below. Effective Engineering Layout of Drainage Infrastructure Was Main Element in Longevity of Machu Picchu. 


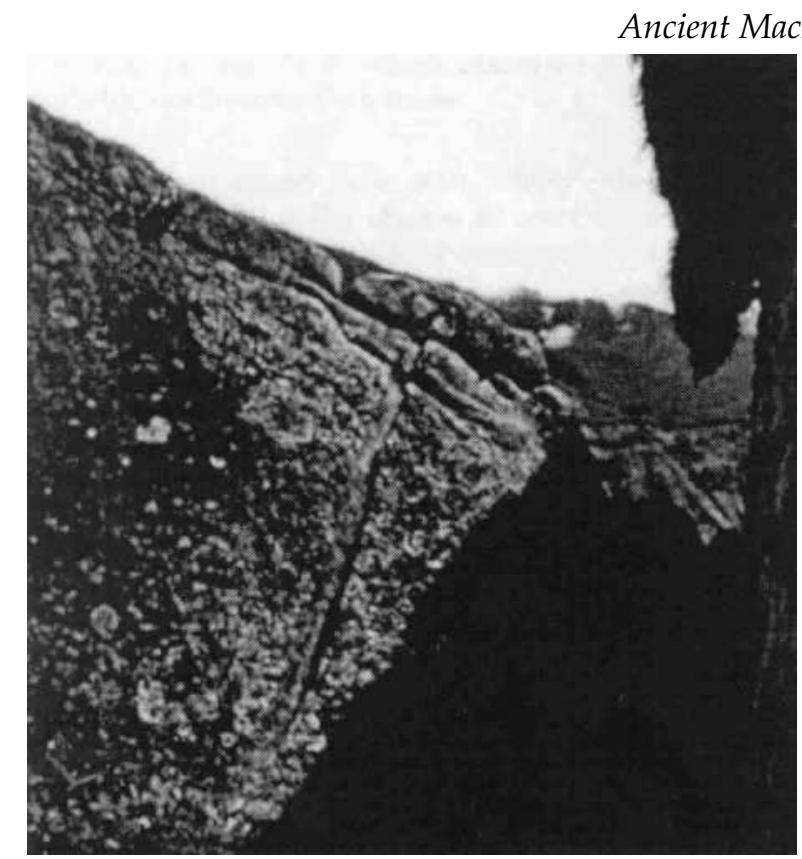

Figure 9. Drip Line Cut into Stone behind Southern Wayrona Near the Sacred Rock. Originally, Thatched Roof Extended Out to Drip Line.

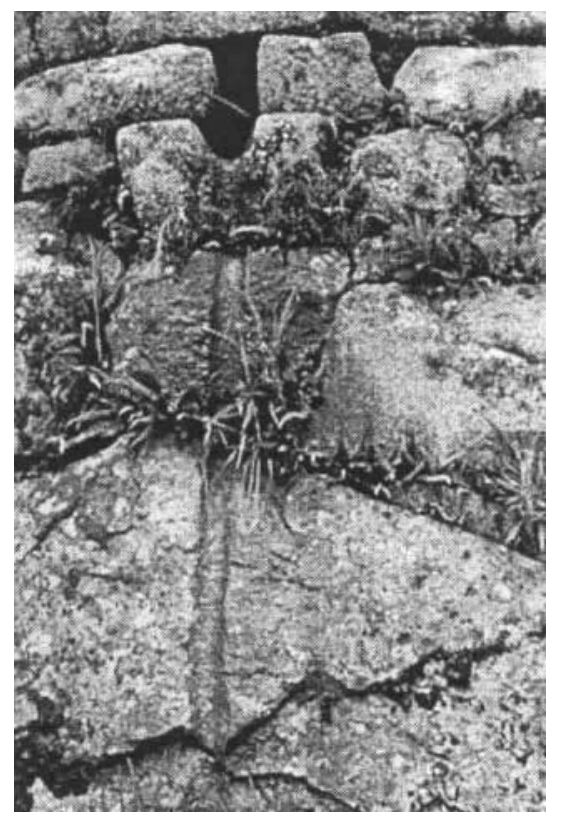

Figure 10. Engineers Strategically Placed 129 Surface Drainage Outlets in Walls to Drain Interior Ground Surfaces. This Drainage Outlet Was Fitted with Vertical Channel to Avoid Splash.

\section{SURFACE RUNOFF}

The ancient designers of Machu Picchu did not have the benefit of a written language, the wheel, or iron. The building of a well-planned community with a substantial infrastructure in a remote mountainous environment would be difficult even under modern conditions. Without the common "tools" of modern day life, it would seem almost impossible. Nevertheless, using techniques developed by previous cultures, their own trial and error, and techniques transferred from one generation to another by word of mouth, the Inca builders were able to empirically size and design a surface drainage system that was remarkably effective (Moseley 1992).

One cannot speculate as to how the drainage system was conceived or how the empirical criteria were developed. Undoubtedly, the long periods of building by pre-Inca Andean empires, such as the Wari and Tiwanaku, would have given the Inca builders much opportunity to judge and copy what would work (Wright 1998). 


\section{Drainage Criteria}

By studying the writers' map of Machu Picchu and analyzing urban drainage basins, and by computing the capacity and documenting the spacing of the drainage outlets, rough empirical Inca drainage design criteria were reconstructed. It was determined that a typical urban wall drainage outlet at Machu Picchu was based upon criteria equivalent to those in Table 5. For agricultural drainage, standards of design and construction were uniformly applied.

Table 5. Table 5. Urban Surface Runoff Criteria for Wall Drainage Outlets

\begin{tabular}{|c|c|}
\hline Primary (1) & Magnitude (2) \\
\hline Tributary area per drainage outlet & $200 \mathrm{~m} 2$ \\
\hline Drainage outlet size, typical & $10 \mathrm{by} 13 \mathrm{~cm}$ \\
\hline Drainage outlet capacity, maximum & $650 \mathrm{~L} / \mathrm{min}$ \\
\hline Design rainfall intensity & $200 \mathrm{~mm} / \mathrm{hour}$ \\
\hline Rational formula runoff "C" & 0.8 \\
\hline Design flow per drainage outlet & $500 \mathrm{~L} / \mathrm{min}$ \\
\hline $\begin{array}{c}\text { Note: The writers do not assume that Inca had formalized criteria. Parameters shown represent approximate } \\
\text { empirical equivalents. }\end{array}$ \\
\hline
\end{tabular}

The surface drainage for the agricultural terraces is laid out with terrace slopes suitable for directing any surface runoff lengthwise to the adjacent downslope drains. Inspection of the terraces by the writers and examination of photographs taken in 1912 by Hiram Bingham indicate little erosional evidence of surface runoff, even after four centuries of no maintenance and significant rainfall. The writers concluded that the surface infiltration of rainfall to the subsoil drainage system was highly effective. The Test Pit 6 excavation in the plaza west of the Temple of the Condor confirmed the adequacy of the subsurface system. The parallel surface drainage system for the agricultural terraces, for the most part, provided redundancy and a drainage safety factor for any high-intensity rainstorm events.

Soil test results for the agricultural terraces demonstrated that the hand-placed topsoil was sandy loam having an approximate infiltration rate of $10 \mathrm{~cm} / \mathrm{h}$ and an available water holding capacity of about 0.14 . The underlying deep, loose stone drainage zone has a permeability of approximately $12 \mathrm{~L}$ per day per square centimeter, with a storage coefficient estimated at 0.15 .

\section{PLAZA SUBSURFACE DRAINAGE}

While the authors were denied permission by the INC to excavate or drill test holes into the agricultural terraces and urban plazas, an INC archaeologist conducted excavations at six locations to provide soil samples for laboratory testing by the writers. In Test Pit 6 , which measured 2 by $2 \mathrm{~m}$, three remarkable discoveries were made:

1. An ancient buried stone wall, which either represented an early (1450 A.D.) change in construction plans or a temporary retaining wall for construction purposes (Fig.6).

2. A subsurface layer of loose rock and stone chips at depth for underground drainage. The rock chips found in the plaza represented a portion of the recycling of the thousands of cubic meters of waste chips from the stonecutters.

3. A gold bracelet that had been carefully placed at the foot of the buried stone wall between two guard rocks, perhaps as an offering to Pachamama (Earth Mother).

The subsurface chipped rock stratum was about $1 \mathrm{~m}$ thick with an estimated coefficient of permeability of about $160 \mathrm{~m} /$ day and detention capacity of about $150 \mathrm{~L} / \mathrm{m}^{3}$. As a result, the deep percolation from a major rainfall event could be temporarily stored in the subsurface chipped rock stratum and slowly released to the downstream subsurface discharge point at a modest rate without causing a high groundwater table, which otherwise would have led to instability of the plaza and its soils. 
The plaza areas were also used to receive and dispose of storm drainage from adjacent urbanized tributary basins via infiltration and subsurface runoff. Again, as a safety factor, the Inca engineers also constructed surface drainage facilities for the plaza area.

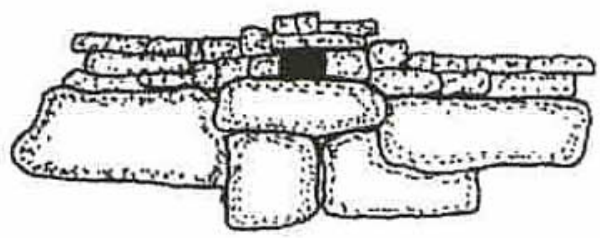

a) Change of stone type outlet

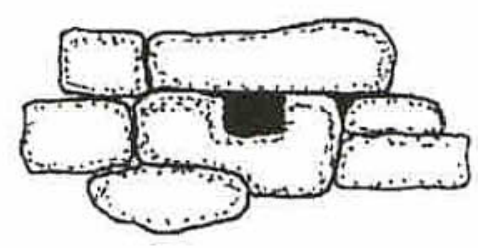

c) Channeled stone outlet

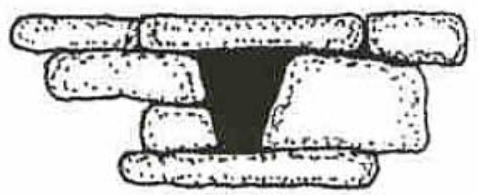

b) Trapezoidal outlet

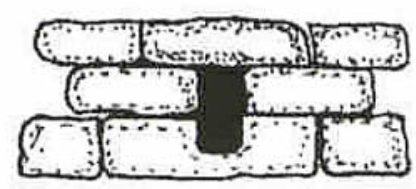

d) Channeled stone outlet with second course

Figure 11. Typical Surface Drain Outlets in Building Walls at Machu Picchu.

\section{SPECIAL DRAINAGE FACILITIES}

The descriptions of the general drainage features and criteria for Machu Picchu provide evidence to support Hiram Bingham's estimate of Inca engineering capabilities. However, the investigation of specific drainage features demonstrates the special care taken by the ancient designers on a site-specific basis. Fig. 11 illustrates details of Inca stone wall drainage outlets at Machu Picchu. Specific facilities are described below.

\section{Emperor's Residence}

Much like the entrance to a department store in a shopping center, where surface drainage is a necessity, the entrance to the emperor's residence in Machu Picchu was well drained. A small channel was constructed from west to east at the single entrance to the royal residence. The channel then passes through a retaining wall via a drainage outlet, where the water would drop about $0.7 \mathrm{~m}$ to another west east flowing channel with a $2 \%$ grade. Five meters downstream, a drainage outlet and channel from the emperor's bath area joined this channel. The channel then penetrated another exterior wall and continued to another drainage outlet, which discharged to a channel along a main pathway.

The emperor's entrance drainage system, because of its fine construction and stonework, was long thought to be an additional fountain somehow supplied with an underground conduit from Fountain 1 . The special surface drainage at this location provides a good example of the care taken to ensure that stormwater would be properly conducted to a suitable discharge point.

\section{Sacred Rock}

The Sacred Rock is flanked by two three-sided and thatched roofed buildings called wayronas. Here, rainfall off the thatched roofs drops onto the small plaza between the wayronas, where peripheral surface drains carry the stormwater west to a low retaining wall containing three wall drainage outlets. These discharge to the large plaza area separating the East and West Urban Sectors, thus avoiding ponding of surface water.

Behind the southern wayrona, a large rock has a drip and drainage channel carved into it (Fig. 9). Water from the roof would drip onto the rock and be carried away from the wayrona's foundation. The location of the drip channel indicates that the Inca thatched roof was much thicker than the reconstructed thatched roof. 


\section{Agricultural Terrace Horizontal Drain}

During the period of occupation and while under construction, the Inca builders experienced ground slippage in the agricultural terrace area adjacent to the Main Drain (Dry Moat).The slide was satisfactorily stabilized, but not before the Inca workmen had taken effective steps to control surface water runoff.

A large cross-section interceptor surface drain was constructed from south to north at the base of a long slope and immediately above the domestic water supply canal (Fig. 12). The steep sloping interceptor drain, about 42 $\mathrm{m}$ long, terminated at the Main Drain after passing through the south wall of the Main Drain. Much of the uphill slope of this formerly unstable area is void of agricultural terraces, indicating that the builders of Machu Picchu decided not to construct agriculture terraces in the area.

Field evidence consisting of an adjacent granite stairway free of damage but with post-construction terrace wall deflections, shows that the slide occurred during the period of construction and that the slope had been satisfactorily stabilized prior to the Inca abandonment of Machu Picchu.

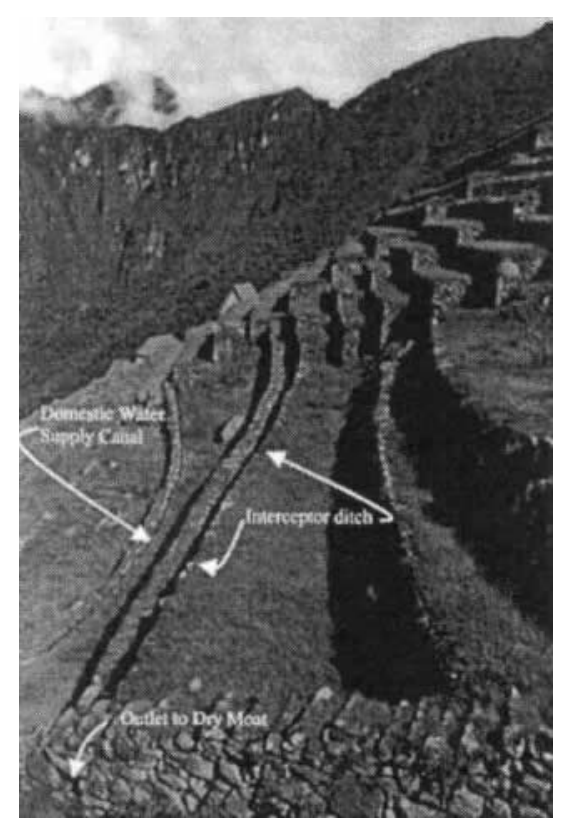

Figure 12. Interceptor Drain Running across Agricultural Sector and Emptying into Dry Moat. Interceptor Drain not only Diverted Surface Water Away from Domestic Water Supply Canal, but also from Troublesome Landslide Area.

\section{EXPLORATION}

During 1996 1997, the paleohydrological team explored the lower east flank of Machu Picchu for additional hydraulic works because, following a 1969 forest fire, Valencia Zegarra (1998) had noted five groups of terraces and several fountains there. Five ancient fountains were found in the rainforest along with the terraces (Wright 2000).

A September 1998 excavation permit from the government allowed excavation of the fountains, two of which were ceremonial fountains that were put into operation again after being buried for over four centuries (Fig. 13). 


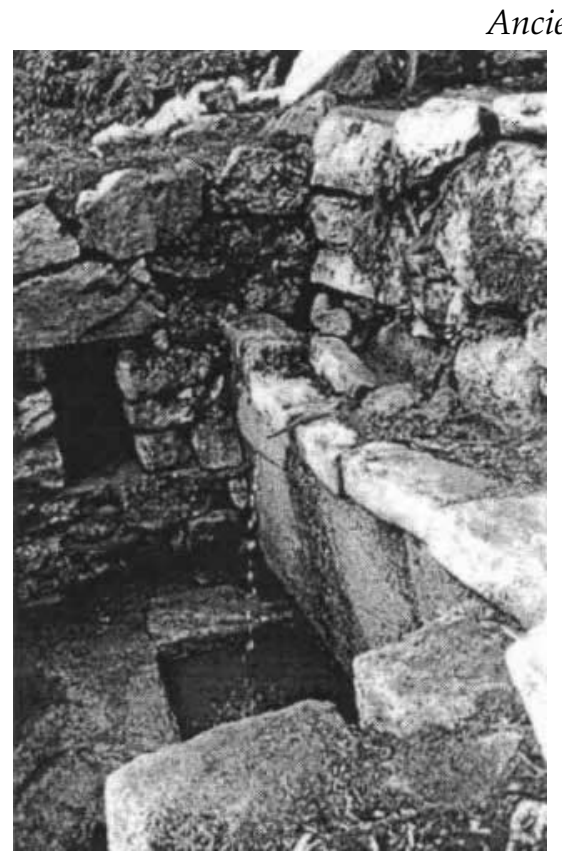

Figure 13. Fountain 1, Immediately After Excavation. Operational Hydraulics Provided Drinking Water Source for Archaeological Crew.

The 1998 field exploration resulted in more than the excavation of the fountains: a previously unknown Inca trail was discovered. The trail is typically $2 \mathrm{~m}$ wide, with many excellent granite staircases ranging up to $3 \mathrm{~m}$ wide (Fig. 14). The Inca trail route was followed through the thick rainforest all -the way down to the Urubamba River, where the ancient low water crossing was found. The trail is judged by the writers as being the primary trail from Machu Picchu to the easterly Vilcabamba region.

The trail infrastructures included formalized drainage works ranging from subsurface channels to surface drains and well-constructed terraces to control surface runoff and provide slope stability. The trail and terraces were found to be in excellent condition, free of landslides and erosion. Damage to two of the fountains had occurred as a result of rockfalls from above.

\section{SUMMARY OF FINDINGS}

The Inca drainage planning at the royal estate of Machu Picchu was well conceived and constructed. The surface and subsurface drainage works were built to manage the nearly $2,000 \mathrm{~mm}$ of average rainfall per year and to protect the magnificent royal estate from damage due to potential landslides, settlement, and erosion. Hiram Bingham was correct in 1913 when he reported to the world that the "Inca were good engineers" ( Bingham 1913).

The agricultural terraces required no irrigation; they were well drained and also provided an important visual amenity to the community. When Bingham photographed the terrace in 1912, he recorded that, despite being "lost" for centuries, the stone terrace walls were still in nearly perfect condition.

The climate during the Inca primary period of occupation, 1450 to 1540, was similar to the modern climate. It has been demonstrated that the site was not abandoned due to a domestic water shortage.

The drainage scheme of Machu Picchu is based on orderly and well-planned surface and subsurface drainage. An empirical system of sizing and location of drainage outlets worked well for the Inca builders. The system was likely based on trial and error methods of the Inca and centuries of experience of preceding Andean empires. 


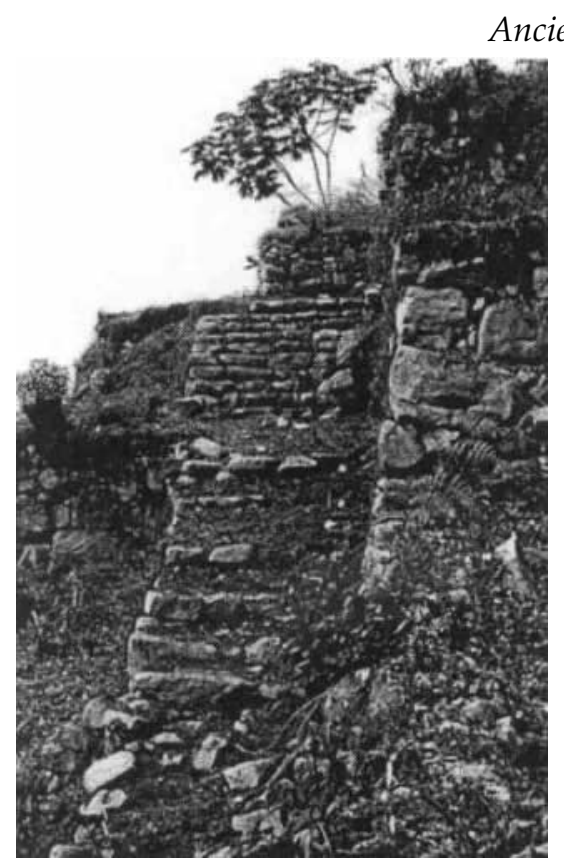

Figure 14. Main Inca Trail from Machu Picchu to Urubamba River Lying Adjacent to Fountains 3, 4, and 5 on Eastern Flank of Ridge.

The remarkable subsurface drainage works found under the plaza provided a stormwater infiltration and disposal area. The thick layer of rocks and waste stone chips provided adequate permeability for flow, as well as a subsurface storage reservoir to avoid a high water table condition during high-intensity rainstorms.

The Inca ingenuity for constructing effective drainage works is exemplified by the Royal Residence, Sacred Rock, and agricultural terrace area. The Inca builders constructed Machu Picchu to last for an eternity, and in doing so, they built good drainage facilities and foundations that would withstand the elements.

\section{APPENDIX. REFERENCES}

Bingham, H. (1913). "In the Wonderland of Peru." Nat. Geographic Mag., April 23, 387573.

Bingham, H. (1930). Machu Picchu: A citadel of the Incas. Yale University Press, New Haven, Conn.

Caillaux, V. C. (n.d.) La geologia en la conservacion del santuario historico de Machu Picchu.

Marocco, R. (1977). "Geologie des Andes Peruviennes: Un segment W.E. de la chaine des Andes Peruviennes; la deflexion D'Abancy-Etude geologique de la Cordillere Orientale et des hauts plateaux entre Cusco et San Miguel," PhD thesis, Academie de Montpellier, Universite des Sciences et Techniques de Languedoc, Montpellier, France.

Moseley, M. E. (1992). The Incas and their ancestors: The archaeology of Peru . Thames and Hudson, London.

Rowe, J. H. (1990). "Machu Picchu a la luz de documentos de siglo XVI." Historica, 14(1), 139154.

Thompson, L. G., and Moseley-Thompson, E. (1989). "One-half millennia of tropical climate variability as recorded in the stratigraphy of the Quelccaya ice cap, Peru." Geophysical Monograph, American Geophysical Union, 55.

Thompson, L. G., Moseley-Thompson, E., Bolzan, J. F., and Koci, B. R. (1985). "A 1500-year record of tropical precipitation in ice cores from the Quelccaya ice cap, Peru." Science, 229, 229(4717), 971973.

Thompson, L. G., Moseley-Thompson, E., Dansgaard, W., and Grootes, P. M. (1986). "The Little Ice Age as recorded in the stratigraphy of the tropical Quelccaya ice cap." Science , 234(4774), 361364.

Thompson, L. G., Moseley-Thompson, E., and Morales, Arnao B. (1984). "El oscillation events recorded in the stratigraphy of the Nino-southern tropical Quelccaya ice cap, Peru." Science, 226, 226(4670), 5052.

Thompson, L. G., Moseley-Thompson, E., and Thompson, P. A. (1992). "Reconstructing interannual climate variability from tropical and subtropical ice-core records." El Nino historical paleoclimatic aspects of the southern oscillation, Diaz, H. F., and Markgraf, V., eds., Cambridge University Press, Cambridge, U.K. 
Tropical ice core paleoclimatic records: Quelccaya Ice Cap, Peru, AD 470 to 1984 . (1986). Nat. Geographic Data Ctr., Nat. Oceanic and Atmospheric Admin., Byrd Polar Res. Ctr., Ohio State University, Columbus, Ohio, distributed by NGDC, Boulder, Colo.

Valencia Zegarra, A. (1998). "Excavaciones en las fuentes del flanco oriental de Machu Picchu." Rep. to Instituto Nacional de Cultura, Universidad Nacional de San Antonio Abad del Cusco, Cusco, Peru.

Valencia Zegarra, A., and Gibaja Oviedo, A. (1992). Machu Picchu: La investigacion y conservacion del monumentos arqueolo 'gico despues de Hiram Bingham. Municipalidad del Qosqo, Peru, Cusco.

Wright, K. R. (1996). "The unseen Machu Picchu: A study by modern engineers." South Am. Explorer, 46, Winter, 416.

Wright, K. R. (1998). "The lessons of history, El and the fall of Nino empires." South Am. Explorer, 53.

Wright, K. R. (2000). "Inca trail discovery at Machu Picchu." South Am. Explorer, in press.

Wright, K. R., Kelly, J. M., and Valencia Zegarra, A. (1997a). "Machu Picchu: Ancient hydraulic engineering." J. Hydr. Engrg., ASCE, 123(10), 838843.

Wright, K. R., Witt, G. D., and Valencia Zegarra, A. (1997b). "Hydrogeology and paleohydrology of ancient Machu Picchu." Ground Water, 35(4), 660666.

Wright, K. R., Wright, R. M., Jensen, M. E., and Valencia Zegarra, A.(1997c). "Machu Picchu ancient agricultural potential." Appl. Engrg.in Agr., 13(1), 3947.

Wright Water Engineers, Inc. (1996). Letter report to the Instituto Nacional de Cultura Departmental Cusco reporting findings of the soil sample testing at Colorado State University. (Results may be obtained directly from CSU. Dr. James Self, Colorado State University, Soil, Water and Plant Testing Laboratory, Room A319, Natural and Environmental Science Building, Fort Collins, CO 80523 1120.)

\section{FOOTNOTES}

1. Pres., Wright Water Engineers, Inc., 2490 W. 26th Ave., Suite 100A, Denver, CO 80211; Dir., Machu Picchu Paleohydrological Survey.

2. Registered Archaeologist, Peru; Prof., Dept. of Anthropology and Archaeology, Universidad Nacional de San Antonio Abad del Cusco, Cusco, Peru.

3. Sr. Consultant, Wright Water Engineers, Inc., 2490 W. 26th Ave., Suite 100A, Denver, CO.

Note. Discussion open until May 1, 2000. To extend the closing dateone month, a written request must be filed with the ASCE Manager of Journals. The manuscript for this paper was submitted for review and possible publication on December 10, 1998. This paper is part of the Journal of Irrigation and Drainage Engineering, Vol. 125, No. 6, November/December, 1999. ASCE, ISSN 0733-9437/99/0006-0360-0369/\$8.00 \$.50 per page. Paper No. 19153. 